University of Nebraska - Lincoln

DigitalCommons@University of Nebraska - Lincoln

1963

\title{
Paleontologic Investigations at Big Bone Lick State Park, Kentucky: A Preliminary Report
}

\author{
C. Bertrand Schultz \\ University of Nebraska State Museum \\ Lloyd G. Tanner \\ University of Nebraska State Museum \\ Frank C. Whitmore Jr. \\ U.S. Geological Survey \\ Louis L. Ray \\ U.S. Geological Survey \\ Ellis C. Crawford \\ William P. Behringer Memorial
}

Follow this and additional works at: https://digitalcommons.unl.edu/usgsstaffpub

Part of the Earth Sciences Commons

Schultz, C. Bertrand; Tanner, Lloyd G.; Whitmore, Frank C. Jr.; Ray, Louis L.; and Crawford, Ellis C., "Paleontologic Investigations at Big Bone Lick State Park, Kentucky: A Preliminary Report" (1963). USGS Staff -- Published Research. 234.

https://digitalcommons.unl.edu/usgsstaffpub/234

This Article is brought to you for free and open access by the US Geological Survey at DigitalCommons@University of Nebraska - Lincoln. It has been accepted for inclusion in USGS Staff -- Published Research by an authorized administrator of DigitalCommons@University of Nebraska - Lincoln. 


\section{Paleontologic Investigations at Big Bone Lick State Park, Kentucky: A Preliminary Report}

Abstract. The Big Bone Lick area in Kentucky, the first widely known collecting locality for vertebrate fossils in North America, is being investigated for further faunal and geologic evidence. Mammal bones, ranging in age from Wisconsin (Tazewell?) to Recent, were recovered in 1962 from four different faunal zones in two terrace fills.

Big Bone Lick, a swampy area surrounding salt and sulfur springs, is located at the confluence of Big Bone Creek and Gum Branch in Boone County, Kentucky, about 20 miles $(32 \mathrm{~km})$ southwest of Cincinnati, Ohio, and 2 miles $(3.2 \mathrm{~km})$ east of the Ohio River. This famous locality, the first widely known collecting area for vertebrate fossils in America, is now in part Big Bone Lick State Park. The first white man to have visited Big Bone Lick appears to have been Major Charles LeMoyne de Longueuil, who was in command of French and Indian troops from Canada. In 1739, Longueuil found many big bones and teeth at the edge of a marshy area, and made a small collection of the fossils. These specimens were later sent to France for preservation and study. During the ensuing two centuries several large and many small collections of late Pleistocene to modern bones have been made here.

Osborn (1), Jillson (2), and Simpson (3) have recounted the history of early collecting at Big Bone Lick. Although thousands of bones were collected in the early days, few found before 1807 have survived. In that year President Thomas Jefferson sent a collecting expedition to Big Bone Lick at his own expense. William Clark, the leader, had had experience in fossil collecting on the Lewis and Clark Expedition to the 29 NOVEMBER 1963
West. In September and October 1807 , Clark, with the aid of ten assistants, made a large collection which was shipped to President Jefferson. For several months after its arrival in Washington the collection was "spread in a large room" in the White House, where it was examined by Caspar Wistar, probably the foremost American anatomist of that time (4). The collection was divided into three parts: one for the American Philosophical Society in Philadelphia, one for the Museum d'Histoire Naturelle de France in Paris, and a smaller one for the President's personal collection.

The Clark-Jefferson bone collection, and a few exceptionally good specimens collected and preserved by others during the early years of the 19th century, have provided the basis for most studies of the Big Bone Lick fauna. Seventeen species of large mammals of Pleistocene and Recent age have been recovered there. Type specimens of mammals, Bootherium bombifrons (Harlan), Bison antiquus Leidy, and Cervalces scotti (Lydekker), were found at Big Bone Lick, and the type specimens of two other species, Mylodon harlani Owen and Tapirus haysii Leidy, may have come from there, although data on their original localities are conflicting.

It should be noted that the type three important species of Pleistocene specimen of Bison latifrons (Harlan) did not come from Big Bone Lick, as many writers have reported, but was found at a nearby locality "in the bed of a creek falling into the Ohio River, a dozen or more miles north of Bigbone-lick, Kentucky" (5). Apparently it was derived from Pleistocene deposits in the vicinity of Woolper Creek, Boone County, Kentucky. No identifiable remains of $B$. latifrons have been found at Big Bone Lick, and most specimens from there that have been attributed to this species appear to be Bison antiquus.

Since the time of Jefferson, the largest collection made at Big Bone Lick was that of N. S. Shaler in 1868 for the Museum of Comparative Zoology at Harvard College. Shaler tried to determine a stratigraphic succession at the site and at one place he thought he had unraveled it, but no description by him has been found. In any event, it appears that his excavations reached a depth of only $8 \mathrm{ft}\left(2 \frac{1}{2} \mathrm{~m}\right)$. In studying the bison in Shaler's collection, Allen (6) found that most bones were of the modern species, Bison bison. Hay (7) aptly summarized the work that had been done at Big Bone Lick when he reported: "Notwithstanding the amount done at Big Bone Lick, the geology of the locality and especially of the bone-bearing levels is not well known. Most persons who have labored there were interested almost wholly in getting as many bones as possible and then in getting away."

Since 1934 we have spent several brief periods there assessing the site. The lack of stratigraphic control at such an important collecting locality prompted us to collect fossils and study the stratigraphy of the area. We spent 6 weeks at Big Bone Lick in July and August 1962 (8), and it is anticipated that field studies of the site will be completed by the fall of 1966 . In addition to investigating the stratigraphy and paleoecology of the site, and collecting stratigraphically located topotypes of species described from there, we hope to determine the horizons from which specimens in the older collections were recovered.

The history of the Big Bone Lick deposits, before modification by human activities during the past two centuries, corresponds to that of the nearby Ohio River, to which Big Bone Creek is a tributary. Although glacial tills of Kansan and Illinoian age crop out near the 
site, the bone-bearing deposits are entirely related to events during and subsequent to the Wisconsin glacial age.

Remnants of a terrace along the walls of Big Bone Valley, adjacent to the site, are composed of lacustrine clayey silt, deposited at the time of the Tazewell advance of the ice sheet of Wisconsin age. They represent backwater alluviation in Big Bone Valley which culminated about 18,500 years ago when the nearby Ohio was choked by a valley train of glacial outwash. After alluviation in Tazewell time, intervals of erosion and of alluviation produced two lower terraces of postTazewell age (Fig 1), now represented by low remnants above the level of the modern floodplain of the creek. These lower terraces, 10 and $22 \mathrm{ft}(3$ and $62 / 3 \mathrm{~m}$ ) above the creek level, are subject to inundation [the $10-\mathrm{ft}(3 \mathrm{~m})$ terrace was flooded briefly during July 1962]. Precise dating of the two terraces of post-Tazewell age awaits further field study and carbon-14 analyses of wood recovered from them.

At the base of a natural exposure cut by Big Bone Creek into the higher terrace of post-Tazewell age, a compact, calcareous, "blue" clayey silt cut by iron-stained fractures is exposed for 3 to $5 \mathrm{ft}\left(1\right.$ to $\left.1 \frac{1}{2} \mathrm{~m}\right)$ above the creek bed. A Tazewell age has been tentatively assigned to this layer in the belief that it represents uneroded lacustrine backwater alluvium deposited during development of the oldest terrace, of Tazewell age. Unconformably above the "blue" clayey silt is an ironstained, calcareous, gravelly, sandy silt, 1 to $3 \mathrm{ft}(1 / 3$ to $1 \mathrm{~m})$ thick, which is cverlain by $15 \mathrm{ft}\left(4 \frac{1}{2} \mathrm{~m}\right)$ of sandy, clayey silt in which a very youthful soil profile has developed.

On the youngest and lowest terrace (see Fig. 1) are the salt springs, now much smaller than they were even in the historic past. Excavations in this terrace revealed 10 to $12 \mathrm{ft}$ ( 3 to $32 / 3 \mathrm{~m}$ ) of sandy and clayey silt, calcareous at depth, overlying a layer of black, humic, gravelly silt which in turn overlies a "blue" clayey silt, presumably the same as that tentatively assigned a Tazewell age elsewhere. Although weathering has leached the surficial material to a depth of $2 \mathrm{ft}(2 / 3 \mathrm{~m})$, no zonal soil profile is apparent.

Collections of vertebrate remains were made in 1962 during excavations in the terraces of post-Tazewell age (University of Nebraska State Museum Collecting Localities KEN-1 and KEN-2). Some 2000 specimens were

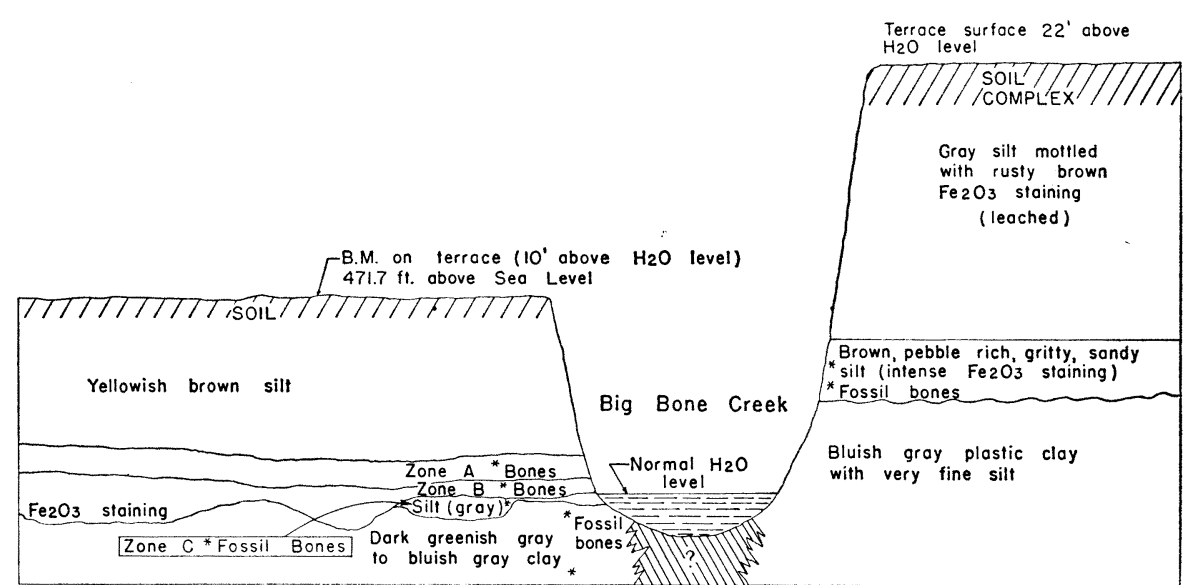

Fig. 1. Diagrammatic cross section showing the main bone-bearing zones below the $10-\mathrm{ft}(3 \mathrm{~m})$ and $22-\mathrm{ft}(62 / 3 \mathrm{~m})$ terraces at the University of Nebraska collecting localities KEN-1 and KEN-2, Big Bone Lick, Kentucky.

recovered and have been prepared, numbered, and identified.

Locality KEN-1, in the lower terrace of post-Tazewell age, is directly north of Big Bone Creek and east of the mouth of Gum Branch. From the terrace surface, $10 \mathrm{ft}(3 \mathrm{~m})$ above the level of Big Bone Creek, approximately $7 \mathrm{ft}(2 \mathrm{~m})$ of barren surficial material was removed by bulldozing an area 130 by $80 \mathrm{ft}(40$ by $24 \mathrm{~m})$. This area was surveyed and laid off into a grid of 10$\mathrm{ft}(3-\mathrm{m})$ squares. Excavation was begun in one square at a time, but as work progressed, several squares were excavated simultaneously. Faces of excavations were kept smooth and were photographed, sketched, and sampled. Bones, sediment samples, and plant remains were located by grid square number, position in square, and depth below ground surface. Character of the alluvium was recorded.

Bones at Locality KEN-1 come from three faunal zones below the terrace surface (Fig. 1).

Zone $\mathrm{A}, 7.0$ to $8.5 \mathrm{ft}(2.1$ to $2.6 \mathrm{~m})$ (buff-brown, mottled silt). Bones recovered represent: Canis sp., Bison bison, Bos taurus, Sus scrofa, Odocoileus virginianus, and Equus caballus. Associated with these modern native and domesticated animal bones were crockery, bricks, worked building stones, wood, seeds, and an occasional reworked bone of an extinct animal. This zone appears to have been disturbed since the coming of the white man and is possibly the site of earlier excavations made by those searching for bones.

Zone $\mathrm{B}, 8.5$ to $11 \pm \mathrm{ft}\left(2.6\right.$ to $\left.3 \frac{1}{2} \mathrm{~m}\right)$ (dark gray to dark brown humic silt and sand). Bones recovered represent: Bison bison, Bison sp., Ovibos sp.,
Cervus cf. canadensis, and Odocoileus sp. Bones of proboscideans, Bison cf. antiquus, and Equus cf. complicatus were found in the basal part of this zone where it overlies a blue-gray silt. The bones appear to have been derived from the underlying clayey silt and reworked by stream action. Abundant bones of Bison bison at this level are associated with wood, roots, nuts, leaves, broken shells of large mollusks, and pieces of flint.

Zone C, 10 to $15+\mathrm{ft}\left(3\right.$ to $4 \frac{1}{2} \mathrm{~m}$ ) (blue-gray silt). Bones recovered represent: Mylodon sp., Mammut americanus, Bison antiquus, Cervalces scotti, Rangifer sp., and Equus cf. complicatus. Only a few squares were excavated in this zone. The contact between Zones $\mathrm{B}$ and $\mathrm{C}$ is irregular. The dark greenish-gray to bluish-gray clay (Tazewell?) under Zone $C$ contains occasional bones and extends from $11 \pm$ to $29+\mathrm{ft}\left(3 \frac{1}{2}\right.$ to $\left.9 \mathrm{~m}\right)$ below the terrace surface.

Locality KEN-2 is in the higher terrace of post-Tazewell age, the surface of which is approximately $22 \mathrm{ft}(62 / 3$ $\mathrm{m})$ above the normal water level of Big Bone Creek, just southeast of the mouth of Gum Branch. The face of the exposure was cleared of vegetation for $80 \mathrm{ft}(24 \mathrm{~m})$ along the creek, and stakes were placed at 10 -ft $(3 \mathrm{~m})$ intervals for horizontal control. Specimens were related to a profile with water level of the creek as the base and a bench mark [altitude $481.3 \mathrm{ft}$ (144.3 m)] on the terrace surface as the top. The bones appear to occur in a single zone ranging from 16.6 to $12.5 \mathrm{ft}$ ( 5 to $3.8 \mathrm{~m}$ ) below the terrace surface. The bone-bearing layer is an iron-stained, calcareous, gravelly, sandy silt, 1 to 3 $\mathrm{ft}(1 / 3$ to $1 \mathrm{~m})$ thick, which uncon- 
formably overlies a "blue" clayey silt. Test excavations in the bone-bearing horizon yielded a number of specimens which were rather uniformly distributed along the $80-\mathrm{ft}(24 \mathrm{~m})$ profile. The faunal assemblage included the following: Mammut americanus, Mammuthus sp., Bison antiquus, Odocoileus sp., and Equus cf. complicatus. Their position in the deposits under the high terrace of post-Tazewell age and the lack of evidence of reworking or mixing with modern faunas indicates that the fossils at this site may be of approximately the same age as Zone $\mathrm{C}$, or the clay layer immediately below it, at KEN-1.

No bones or teeth of small vertebrates were found during the preliminary excavations in 1962, although test screening was done.

In addition to the major excavations at Big Bone Lick in 1962, 15 test holes were drilled with a power auger furnished by the Commonwealth of Kentucky, and samples were taken for analysis and examination for microfauna and microflora. Wood was collected for carbon-14 analysis. A topographic map with a $1-\mathrm{ft}(1 / 3 \mathrm{~m})$ contour interval and a scale of 1 inch $\left(2 \frac{1}{2} \mathrm{~cm}\right)$ to $100 \mathrm{ft}(30 \mathrm{~m})$ was made of the area. Test holes were plotted on this map. Temporary bench marks were established at the collecting localities. Excavations and fossil localities were recorded so that data will be readily available for future reference.

Present investigations indicate three terrace levels at Big Bone Lick above the present floodplain of the creek, the highest being of Tazewell age and the two lower terraces of post-Tazewell age. Distinct bone-bearing alluvial deposits appear to be related to the terrace sequence. Future investigations may re- veal relationships of the alluvial deposits to each other and to the fauna; age determinations will be based on carbon-14 dating of woody material that accompanies the bones. The sequence of terraces appears to be similar to that of the adjacent Ohio Valley, indicating that the history of the site is a part of the regional sequence of events (9).

\section{Bertrand Schultz}

Lloyd G. TANNER

University of Nebraska State Museum, Lincoln 8

Frank C. Whitmore, JR. Louis L. RAY

U.S. Geological Survey,

Washington 25, D.C.

Ellis C. CRAWford

William P. Behringer Memorial

Museum, Covington, Kentucky

References and Notes

1. H. F. Osborn, Science 82, 533 (1935).

2. W. R. Jillson, Big Bone Lick (Standard Printing Co., Louisville, Ky., 1936), p. 164. 3. G. G. Simpson, Proc. Am. Phil. Soc. 86, 130 (1943)

4. H. G. Rice, Jr., ibid. 95, 608 (1951).

5. J. Leidy, J. Acad. Natural Sci. Phila. 7, 372 (1869).

6. J. A. Allen, Mem. Mus. Comp. Zool. Harvard 4, No. 10 (1876).

7. O. P. Hay, Carnegie Inst. Wash. Publ. 322 (1923), 401, 403 (1923).

8. Other members of the field party were: R. A Cochran II, Donald Cox, B. N. Haynes, Gerald Petsche, W. H. Pile, Jr., G. G. Gerald Petsche, W. H. Pile,

9. C. B. Schultz received a grant from the American Philosophical Society; Schultz and L. G. Tanner were awarded a supplemental grant from the University of Nebraska Research Council; and the U.S. Geological Survey furnished funds to F. C. Whitmore and L. L. Ray. Many have contributed to making the preliminary excavations at Big Bone Lick State Park possible. Special thanks are due George Lyon, Kentucky State Dept. of Parks; Roger Arnold, superintendent of Big Bone Lick State Park; William Fitzgerald and Bruce Ferguson of the Big Bone Lick Historical Association; F. W. Johno Lick Historical of exploration Standard Oil Ceputy manager of expla and W. M. Lucas, Florence, Ky. Publication authorized by the director, U.S. Geological
Survey.

1 July 1963 